\title{
IMPLEMENTASI ASAS LEX SPECIALIS DEROGAT LEGI GENERALI DALAM SISTEM PERADILAN PIDANA
}

\author{
Shinta Agustina \\ Fakultas Hukum Universitas Andalas \\ Kampus Limau Manis Padang \\ email: shinta_agustina63@yahoo.com
}

\begin{abstract}
.
This study aims to assess and analyze the application of the principle of lex specialis the derogat legi generali in the Criminal Justice System related to the stages in the criminal justice process, and the form of the indictment in applying the principle of lex specialis the derogat legi generali. The method used is empirical juridical with descriptive analytical. The result shows that this principle is applied in criminal cases that violating the general and special criminal provisions in the Penal Code, the general criminal provisions in the Penal Code and special criminal provisions outside the Penal Code, as well as criminal cases that violating two special criminal acts outside the Penal Code. Regarding the fase of criminal procedure in handling the case under this principle, it is implemented in the adjudication process, using the subsidiarity or cumulative model of charging.
\end{abstract}

Keywords: Lex Specialis Derogat Legi Generali, Criminal Justice System.

\begin{abstract}
Abstrak
Penelitian ini bertujuan untuk mengkaji dan menganalisis penerapan asas lex specialis derogat legi generali dalam Sistem Peradilan Pidana terkait dengan tahapan dalam proses peradilan pidana, dan bentuk surat dakwaan dalam menerapkan asas lex xpecialis derogat legi generali tersebut. Metode penelitian yang digunakan adalah metode yuridis empiris yang bersifat deskriptifanalitis. Hasil penelitian memperlihatkan bahwa asas lex specialis derogat legi generali diterapkan dalam perkara pidana yang mempertemukan ketentuan pidana umum dan khusus dalam KUHP, ketentuan pidana umum dalam KUHP dan ketentuan pidana khusus di luar KUHP, serta perkara pidana yang mempertemukan dua atau lebih ketentuan pidana khusus di luar KUHP. Berkenaan dengan tahapan dalam sistem peradilan pidana, asas ini diterapkan dalam tahap adjudication, yang mengharuskan surat dakwaan dibuat dalam model subsidiaritas atau kumulatif.
\end{abstract}

Kata kunci: Asas Lex Specialis Derogat Legi Generali, Sistem Peradilan Pidana.

\section{A. Pendahuluan}

1. Latar Belakang

Dalam suatu perkara pidana, terdapat perbuatan seseorang yang secara materiil/jasmaniah hanya melakukan satu perbuatan, tetapi melanggar beberapa ketentuan hukum pidana sekaligus (eendaadsche samenloop), baik hukum pidana umum maupun hukum pidana khusus, misalnya melanggar UU Kehutanan dan UU Pemberantasan Tindak Pidana Korupsi (UU
PTPK), atau melanggar UU Perbankan dan UU PTPK, atau melanggar UU Pajak dan UU PTPK.

Praktik penegakan hukum pidana terhadap kasus-kasus demikian, memperlihatkan penerapan hukum yang inkonsisten dan diskriminatif. Dalam kasus DL Sitorus misalnya, yang diduga merugikan negara karena melakukan penebangan hutan di areal yang bukan HPH-nya, hanya dikenakan UU Kehutanan, sementara Adelin

\footnotetext{
1. Emerson Yunto, 2008, Menyelamatkan Pembalak Liar, Hasil Eksaminasi Publik Putusan PN Medan dalam Perkara Tindak Pidana Korupsi dan Illegal Logging, Jakarta, Indonesia Corruption Watch, hlm 15.
} 
Lis, dikenakan UU PTPK dan UU Kehutanan. Dalam kasus tindak pidana perbankan yang melibatkan mantan Dirut Bank Mandiri ECW Neloe, hanya dikenai UU PTPK, ${ }^{2}$ begitu juga Syahrir Sabirin, ${ }^{3}$ padahal perbuatan mereka berada dalam ranah hukum perbankan. Kasus lain dalam ranah hukum yang sama hanya dikenakan Undang-undang Nomor 10 Tahun 1998 tentang Perbankan (Putusan MA Nomor: $615 \mathrm{~K} /$ Pidsus/2010).

Praktik penegakan hukum yang bersifat diskriminatif dan inkonsisten tersebut menimbulkan disparitas pidana, ketidakadilan serta ketidakpastian hukum. Kondisi tersebut disebabkan oleh adanya ketidaksamaan persepsi di antara penegak hukum (ketidaksinkronan kultural) tentang asas lex specialis derogat legi generali, tentang ketentuan hukum pidana khusus, serta model surat dakwaan dalam menerapkan asas tersebut. ${ }^{4}$ Kondisi ini tidak dapat dibiarkan, karena berakibat pada ketidakpercayaan masyarakat terhadap penegakan hukum. Kondisi ini juga menghambat terwujudnya sistem peradilan pidana terpadu karena salah satu karakteristik dari sistem peradilan pidana terpadu (integrated criminal justice system) adalah sinkronisasi, baik sinkronisasi struktural, subtansial, maupun kultural. ${ }^{5}$

Berdasarkan uraian latar belakang di atas, maka penulis akan membahas permasalahan, antara lain: 1) Bagaimanakah penerapan asas lex specialis derogat legi generali dalam Sistem Peradilan Pidana terkait dengan tahapan dalam proses peradilan pidana? 2) Bagaimanakah bentuk surat dakwaan dalam menerapkan asas lex xpecialis derogat legi generali pada Sistem Peradilan Pidana?

\section{Metode Penelitian}

Metode yang digunakan dalam penelitian ini adalah metode yuridis empiris yang bersifat deskriptif analitis, karena mencoba mendapatkan gambaran menyeluruh tentang penerapan asas lex specialis derogat legi generali dalam proses peradilan pidana. Penelitian dilakukan dengan bersandarkan pada asas dan ajaran hukum yang relevan untuk mengkaji permasalahan dimaksud.

\section{Kerangka Teori}

a. Asas Lex Specialis Derogat Legi Generali sebagai Asas Preferensi.

Asas lex specialis derogat legi generali (hukum khusus menyampingkan hukum umum) merupakan salah satu asas preferensi yang dikenal dalam ilmu hukum. Asas preferensi adalah asas hukum yang menunjuk hukum mana yang lebih didahulukan (ứntuk diberlakukan), jika dalam suatu peristiwa (hukum) terkait atau terlanggar beberapa peraturan. Purnadi Purbacaraka dan Soerjono Soekanto mengatakan bahwa:

Maksud dari asas ini adalah bahwa terhadap peristiwa khusus wajib diberlakukan undang-undang yang menyebut peristiwa itu, walaupun untuk peristiwa khusus tersebut dapat pula diberlakukan undang-undang yang menyebut peristiwa yang lebih luas atau lebih umum yang dapat mencakup peristiwa khusus tersebut.

Sementara itu, Eddy OS Hiariej mengemukakan bahwa:

Dilihat dari perspektif politik hukum pidana (penal policy), eksistensi asas 'lex specialis derogat legi generali" sebenarnya merupakan asas hukum yang menentukan dalam tahap aplikasi. Tahap ini merupakan tahap penerapan peraturan perundang-undangan pidana yang telah dilanggar terhadap peristiwa konkrit (ius operatum) melalui proses penegakan hukum. Oleh karena itu, asas "lex specialis" ini menjadi penting bagi aparat penegak hukum ketika akan menerapkan peraturan perundangundangan pidana terhadap perkara pidana yang ditanganinya.

2. Syarifuddin et al, 2006, Benang Kusut Peradilan Korupsi Perbankan: Catatan Hasil Eksaminasi Putusan Neloe dkk, Jakarta, Konsorsium Reformasi Hukum Nasional, hlm 72

3. Eddy OS Hiariej, 2008. Potensi Kejahatan Dalam Analisis Kredit. materi pelatihan tindak pidana perbankan pada Bank BNI, Yogyakarta, hlm 56

4. Shinta Agustina dkk, 2010, Persepsi Aparat Penegak Hukum Tentang Pelaksanaan Asas Lex Specialis Derogat Legi Generali Dalam Sistem Peradilan Pidana, Laporan Penelitian, Padang: LPPM-Unand, hlm 42.

5. Muladi, 1998, Kapita Selekta Sistem Peradilan Pidana, Semarang, Penerbit Undip, hlm 4.

6. Purnadi Purbacaraka dan Soerjono Soekanto, 1983, Perundang-undangan dan Yurisprudensi, Bandung: Citra Aditya Bakti, hlm 8.

7. Eddy OS Hiariej dkk, 2009, Persepsi dan Penerapan Asas Lex Specialis Derogat Legi Generali di Kalangan Penegak Hukum, Laporan Penelitian, Yogyakarta, Fakultas Hukum Universitas Gajah Mada, hlm 5. 
Dalam bidang hukum pidana, asas lex specialis derogat legi generali dinormakan dalam Pasal 63 ayat (2) KUHP yang menentukan bahwa, "Jika suatu tindakan masuk dalam suatu ketentuan pidana umum, tetapi termasuk juga dalam ketentuan pidana khusus, maka hanya yang khusus itu yang diterapkan". Artinya, jika terjadi suatu tindak pidana yang melanggar dua ketentuan hukum pidana atau lebih, yang salah satunya adalah ketentuan hukum pidana umum, dan yang lainnya adalah ketentuan hukum pidana khusus, maka ketentuan hukum pidana khusus itulah yang dikenakan kepada pelakunya.

Namun, KUHP tidak menjelaskan dalam situasi seperti apa, terdapat peristiwa yang melanggar ketentuan pidana umum dan pidana khusus tersebut. Memorie van Toelichting (MvT) hanya menyatakan bahwa: ${ }^{8}$

"Indien het eene strafbare feit slechts is eene bijzonder genoemde soort van het andere, en dus uit zijnen aard daaronder reeds is begrepen, dan geldt de regel lex specialis derogate legi generali, onverschillig of de species zwaarder of lichter wordt gestraft dan het genus, en onverschillig of zij al dan niet een eigen naam heeft.

(Jika suatu tindak pidana hanyalah satu jenis khusus dari suatu perbuatan yang lain, dan dari makna yang ada sudah dipahami, maka berlaku aturan lex specialis derogat legi generali, tanpa mempedulikan apakah yang khusus itu dihukum lebih berat atau lebih ringan daripada yang umum, dan tanpa mempedulikan pula apakah dia memiliki sebutan sendiri).

Menurut Nolte, pada awalnya orang sepakat bahwa dalam peradilan pidana, asas ini hanya diterapkan, bilamana suatu perbuatan memenuhi semua unsur dari suatu tindak pidana yang diatur dalam suatu ketentuan pidana, tetapi juga memenuhi unsur dari suatu tindak pidana lain, yang dirumuskan dalam suatu ketentuan pidana lainnya, yang unsur-unsur dari ketentuan pidana pertama tadi menyatu ke dalamnya. Selaras dengan Nolte, Van Hattum menyatakan bahwa penerapan hukum yang demikian memperlihatkan hubungan kekhususan yang logis dari satu ketentuan hukum pidana dengan ketentuan hukum pidana lainnya, karena semua unsur dari ketentuan pidana yang pertama dapat ditemui juga dalam ketentuan pidana yang terakhir, bahkan ketentuan terakhir ini memiliki unsur lain. ${ }^{10}$ Namun, praktik penegakan hukum pidana kemudian juga memperlihatkan diterimanya penerapan asas tersebut terhadap ketentuan pidana khusus yang sistematis, dimana ketentuan yang lain itu dianggap sebagai ketentuan khusus bukan karena memiliki semua unsur dari ketentuan yang lain, tetapi karena pengaturan atau nama delik atau sejarahnya, merupakan ketentuan yang lebih khusus.

\section{b. Gabungan Tindak Pidana (Samenloop van Strafbare Feiten).}

Penerapan asas lex specialis derogat legi generali dalam hukum pidana terkait dengan pranata hukum gabungan/perbarengan tindak pidana (samenloop atau concursus). Hal ini disebabkan pengaturan asas tersebut berada dalam Bab VI Buku I, dengan judul "gabungan tindak pidana". Simons mengatakan bahwa: ${ }^{12}$

Suatu samenloop van strafbare feiten atau gabungan dari perbuatan-perbuatan yang dapat dihukum itu hanya ada, yaitu apabila perbuatan-perbuatan tersebut telah dilakukan oleh satu orang yang sama dan diantara perbuatan-perbuatan tersebut tidak terdapat suatu putusan hakim yang telah mengadili satu atau lebih perbuatan-perbuatan tersebut.

Dalam keadaan demikian akan terjadi pemberatan pidana, yang disesuaikan dengan ajaran samenloop terhadap berbagai bentuk concursus tersebut. Dalam doktrin hukum pidana dikenal tiga macam bentuk samenloop atau concursus, yaitu (1) concursus idealis atau eendaadse samenloop, sebagaimana

9. H.J. Schmidt, 1891, Geschiedenis van Het Wetboek van Strafrecht: Volledige Verzameling van Regeeringsontwerpen, Gewisselde Stukken, Gevoerde Beraadslagingen enz. Eeerste Deel. Haarlem, H.D. Tjeenk Willink, hlm 478.

10. H.J.A. Nolte, 1949. Het Strafrecht in De Afzonderlijke Wetten: Rechtshistorisch, Rechtsfilosophisch en Systematische Bewerkt, Utrecht, Dekker \& Van De Vegt NV, hlm 251.

11. Utrecht, 1994, Hukum Pidana II, Surabaya, Pustaka Tinta Mas, hlm 176.

12. J. De Hullu, 2009, Materieel Strafrecht: Over Algemene Leerstukken van Strafrechtelijke aansprakelijkheid naar Nederlands Recht, Vierde druk. Deventer, Kluwer, hlm 507. 
diatur dalam Pasal 63 ayat (1) KUHP, (2) concursus realis atau meerdaadse semenloop, yang diatur dalam Pasal 65 dan 66 KUHP, serta (3) voorgezet handeling yang diatur dalam Pasal $64 \mathrm{KUHP}^{13}$

Persoalan utama dalam ajaran gabungan tindak pidana adalah apa yang dimaksud dengan satu perbuatan (een feit) dalam Pasal 63 ayat (1) dan (2) tersebut. Modderman dalam keterangannya untuk rancangan $\mathrm{WvS}$ menjelaskan tentang "men met het lichaamelijke oog eene eenheidziet en met het oog des geetes eene pluraliteit, bijvoorbeeld eene vrouw wordt in het openbaar verkracht"." Jurisprudensi berdasarkan putusan HR pada awalnya juga menerima "perbuatan materil (lichamelijk handeling) itu sebagai parameter satu perbuatan..$^{15}$ Namun, perkembangan praktik penegakan hukum dari putusan HR tahun 1932 yang dikenal dengan Het Oude kijk in 't Jatstraat Arrest, menerima ajaran Aspecten Leer. ${ }^{16}$ Ajaran ini menerima bahwa satu perbuatan materil yang dilihat berdasarkan persfektif hukum pidana, memiliki beberapa arti atau makna, tidak lagi dianggap sebagai satu perbuatan melainkan telah melahirkan meerdaadse samenloop.

\section{c. Model Surat Dakwaan dan Sistem Peradilan Pidana.}

Sistem Peradilan Pidana (SPP) adalah sebuah sistem yang di dalamnya terdapat subsistem yang saling terkait satu sama lain, yakni subsistem Kepolisian, Kejaksaan, Pengadilan dan sub sistem pendukung lainnya seperti Lembaga Pemasyarakatan, Imigrasi, dan instansi lain yang terkait. ${ }^{17}$ Semua subsistem yang terlibat di dalamnya seharusnya berada dalam satu mata rantai yang terpadu, saling mendukung serta terdapatnya suatu sinkronisasi dan koordinasi pelaksanaan tugas dan wewenang. ${ }^{18}$

Muladi mengatakan bahwa dalam SPP harus terdapat sinkronisasi atau keselarasan dalam tiga hal berikut, yaitu: ${ }^{19}$ keselarasan subtansial, keselarasan struktural, dan keselarasan kultural. Yang dimaksud Muladi dengan keselarasan kultural adalah kesamaan persepsi dan pemahaman di antara aparatur penegak hukum tentang peraturan yang ada, tentang asas, konsep, dan prinsip yang berlaku dalam hukum pidana, baik tertulis maupun tidak tertulis. Terkait dengan tema penelitian ini menjadi penting adanya kesamaan pemahaman aparatur penegak hukum tentang asas lex specialis, ajaran gabungan tindak pidana dan model surat dakwaan yang tepat untuk digunakan dalam perkara pidana terkait penerapan asas tersebut.

Dalam proses peradilan pidana, Jaksa Penuntut Umum harus membuat surat dakwaan saat membawa suatu kasus ke pengadilan. Surat dakwaan itu menjadi dasar pemeriksaan perkara di pengadilan, sekaligus juga pedoman pemeriksaan agar proses berjalan sesuai dengan permasalahan dalam perkara tersebut. Surat dakwaan juga menjadi dasar bagi hakim dalam menetapkan putusan dan pembuktian bagi jaksa. Surat dakwaan yang tepat dalam penanganan sebuah perkara pidana, merupakan awal keberhasilan penegak hukum dalam proses penegakan hukum. Model surat dakwaan yang akan digunakan oleh JPU dalam mendakwa seorang pelaku tindak pidana, bergantung kepada perbuatan terdakwa dan alat bukti yang tersedia.

Secara teoritis, dalam doktrin hukum acara pidana dikenal 5 model surat dakwaan, yang masing-masing disesuaikan dengan kasus yang ditangani. Kelima model surat dakwaan tersebut adalah: ${ }^{20}$

1) Surat dakwaan tunggal, yang dibuat untuk perkara pidana dimana hanya ada satu perbuatan dan perbuatan tersebut hanya melanggar satu peraturan;

2) Surat dakwaan alternatif, yang dibuat juga untuk perkara pidana yang hanya ada satu perbuatan dan satu peraturan yang dilanggar. Namun jaksa penuntut

13. PAF Lamintang, 1984, Dasar-dasar Hukum Pidana Indonesia, Bandung, Sinar Baru, hlm 656.

14. H.J. Schmidt, Loc.Cit.

15. Ch. J. Enschede, 2002, Beginselen Van Strafrecht, Kluwer, Deventer, hlm 190.

16. J. De Hullu, Op.Cit, hlm 501.

17. Allen, Ronald Jay, et al, 2002, Comprehensive Criminal Procedure. New York, Aspen Law and Bussiness, hlm. 4.

18 Mardjono Reksodiputro, 1994, Hak Asasi Manusia dalam Sistem Peradilan Pidana. Jakarta, Lembaga Kriminologi dan Pengkajian Peradilan Indonesia, hlm 85.

19.Muladi, 1998, Kapita Selekta Sistem Peradilan Pidana, Semarang, Penerbit Undip, hlm 4.

20. M.Yahya Harahap, 2003, Pedoman Pembahasan dan Permasalahan KUHAP, Buku Kedua, Penuntutan dan Persidangan, Jakarta, Kartini Grup, hlm 450. 
umum masih belum dapat memastikan mana pasal yang sesungguhnya akan terbukti dilanggar oleh terdakwa berdasarkan pemeriksaan di persidangan, maka dibuat dua pasal yang bersifat alternatif(pilihan); ${ }^{21}$

3) Surat dakwaan subsidiaritas (primer subsider), yang dibuat untuk perkara pidana yang melanggar beberapa ketentuan sekaligus, yang biasanya berbentuk delik awal dan delik kualifikasi, sehingga dakwaan dibuat mulai dari pasal yang terberat sampai pada pasal teringan. Surat dakwaan ini sebenarnya juga ditujukan bagi satu perbuatan saja, tetapi terhadap perbuatan tersebut terdapat beberapa ketentuan yang mengaturnya, yang mana ketentuan yang satu bersifat lebih khusus daripada ketentuan lainnya yang bersifat umum;

4) Surat dakwaan kumulatif, yang dibuat untuk perkara pidana, yang pelakunya telah melakukan beberapa tindak pidana sekaligus, dan masing-masing tindak pidana tersebut harus dibuktikan; dan

5) Surat dakwaan gabungan, yaitu surat dakwaan yang dibuat bagi perkara pidana yang pelakunya telah melakukan beberapa perbuatan sekaligus, dan di antara perbuatan tersebut ada yang merupakan delik awal dan delik kualifikasi.

\section{B. Hasil dan Pembahasan.}

1. Implementasi Asas Lex Specialis Derogat Legi Generali dalam Perkara Pidana dengan Karakter Gabungan Tindak Pidana.

Dari empat puluh putusan dalam yurisprudensi Mahkamah Agung yang diteliti, terlihat bahwa dalam menangani perkara pidana dengan karakteristik pelanggaran terhadap hukum pidana umum dan hukum pidana khusus sekaligus, sangat jarang ditemukan pernyataan eksplisit, baik dalam surat dakwaan atau pun dalam putusan hakim, asas lex specialis derogat legi generali diterapkan. Begitu pula sangat jarang ditemukan, pernyataan eksplisit bahwa dalam perkara demikian, Pasal 63 ayat (2) KUHP diterapkan. Dari keseluruhan putusan perkara pidana yang diteliti, pernyataan tentang keharusan diberlakukannya hukum pidana khusus dalam perkara tersebut, hanya ditemui dalam 3 perkara. Namun demikian, peneliti berpandangan terdapat penerapan asas ini secara tersirat, dengan mengkaji bentuk perbuatan yang secara materil hanya satu (een feit), model surat dakwaan yang digunakan, serta pertimbangan hakim dalam memutuskan terdakwa bersalah melakukan tindak pidana dalam dakwaan primer atau dalam dakwaan kesatu.

Asas ini diterapkan pada perkara pidana yang merupakan gabungan tindak pidana dari satu perbuatan (eendaadse samenloop). Hal ini terlihat dari model surat dakwaan yang digunakan dalam menangani perkara pidana tersebut. Bagian terbesar perkara ditangani dengan model dakwaan subsidiaritas dan kumulasi terhadap perbuatan yang merupakan gabungan tindak pidana dari satu perbuatan, baik yang melanggar ketentuan umum (delik pokok) dan ketentuan khusus dalam KUHP (delik yang dikualifikasi (gequalifiseerde delict), maupun delik yang lebih ringan (geprivilegieerde delict), atau yang melanggar ketentuan umum dalam KUHP dan ketentuan khusus di luar KUHP, ataupun yang melanggar dua ketentuan khusus di luar KUHP.

Dalam perkara pidana yang melanggar ketentuan umum dan khusus dalam KUHP, selalu didakwakan dengan dakwaan subsidiaritas (primer subsider). Dakwaan primer menggunakan pasal delik yang dikualifikasi, sedangkan dakwaan subsider atau lebih subsider, dikenakan ketentuan umum (delik pokok). Misalnya dalam perkara penggelapan yang mengenakan Pasal 374 KUHP sebagai dakwaan primer dan Pasal 372 KUHP sebagai dakwaan subsider (Perkara Nomor $71 \mathrm{~K} / \mathrm{Kr} / \mathrm{Pid} / 1993$ ), dalam perkara matinya orang dengan Pasal 340 KUHP sebagai dakwaan primer, Pasal 339 KUHP sebagai dakwaan subisider, Pasal 353 ayat (1) sebagai dakwaan lebih subsider, serta Pasal 351 ayat (3) KUHP sebagai dakwaan lebih subsider lagi (Perkara Nomor 119 $\mathrm{K} / \mathrm{Pid} / 1982$ ). Sementara dalam perkara pidana yang melanggar ketentuan umum dalam KUHP dan ketentuan khusus di luar 
KUHP, digunakan surat dakwaan subsidiaritas dan surat dakwaan kumulasi. Contoh: Pasal 2 UU Perlindungan Anak sebagai dakwaan primer dan Pasal 290 ayat (2) KUHP sebagai dakwaan subsider (Perkara Nomor 134/K/Pidsus/2009).

Kedua model surat dakwaan tersebut juga digunakan dalam menangani perkara pidana yang melanggar dua atau lebih ketentuan hukum pidana khusus di luar KUHP. Diantaranya dakwaan subsidiaritas dalam perkara 89/K/Kr/1968, yang menggunakan UU Nomor 11 PNPS 1963 sebagai dakwaan primer, Perpu Nomor 24 tahun 1960 sebagai dakwaan subsider, sementara dakwaan lebih subsider Pasal 378, dan lebih subsider lagi Pasal 372 KUHP. Begitu juga dalam perkara Nomor: 98/K/Kr/1974, yang menggunakan model surat dakwaan kumulasi dengan Pasal 1 ayat (1) sub b UU Nomor 3 Tahun 1971 sebagai dakwaan kesatu, Pasal 1 ayat (1) sub c UU Nomor 3 Tahun 1971 sebagai dakwaan kedua, dan Pasal 25 angka II c, d, dan e Ordonansi Bea jo Pasal 1sub 1 hurufh jo Pasal 4 UU No 7/Drt/1955.

Dari keseluruhan kasus yang didakwa secara subsidiaritas, semua dinyatakan bersalah melakukan tindak pidana dalam dakwaan primer dan dipidana dengan pidana berdasarkan dakwaan primer tersebut. Hal ini sesungguhnya menimbulkan pertanyaan, mengapa pasal atau ketentuan umum tetap didakwakan jika dari alat bukti yang ada sudah diketahui bahwa perbuatan terdakwa memenuhi ketentuan khusus. Terhadap pertanyaan tersebut, bagian besar responden mengatakan bahwa hal ini merupakan strategi dari JPU untuk berjaga-jaga jika sampai di persidangan ada saksi yang mencabut keterangan, hingga unsur khusus dalam ketentuan khusus tadi bisa saja menjadi tidak terbukti. Dengan kata lain, JPU menggunakan model dakwaan subsidiaritas, bukan karena menerapkan asas lex specialis derogat legi generali, tapi sebagai strategi agar terdakwa tidak lepas dari jerat hukum. Namun, pemilihan ketentuan khusus sebagai dakwaan primer sebenarnya secara implisit menunjukkan bahwa dalam hal ini ada penerapan asas lex specialis derogat legi generali, bukan hanya persoalan strategi dalam penuntutan.

Kesadaran tentang perlunya ketentuan khusus diterapkan terlebih dahulu dalam perkara demikian, juga terlihat pada pemilihan ketentuan khusus yang dijadikan dakwaan primer dan ketentuan KUHP sebagai dakwaan subsider. Sementara dalam model dakwaan kumulasi, ketentuan khusus di luar KUHP menjadi dakwaan kesatu, dan ketentuan KUHP sebagai dakwaan kedua, atau ketiga. Hal yang menarik adalah penerapan beberapa ketentuan khusus di luar KUHP yang terdapat dalam dakwaan kumulasi. Dari putusan dalam perkara tersebut, tidak terdapat penjelasan tentang pertimbangan JPU atau hakim terhadap penggunaan beberapa ketentuan tersebut. Misalnya, untuk menjadikan UU Perlindungan Anak sebagai dakwaan kesatu, sementara UU P-KDRT sebagai dakwaan kedua, dan seterusnya. Atau penggunaan UU Nomor 3 Tahun 1971 sebagai dakwaan kesatu dan kedua, serta Ordonasi Bea jo UU Nomor 7 Drt Tahun 1955 sebagai dakwaan ketiga.

Namun, asumsi peneliti adalah bahwa penegak hukum menganggap perbuatan pelaku, memang melanggar beberapa ketentuan hukum pidana khusus sekaligus atau memenuhi rumusan delik dalam beberapa UU, sehingga masing-masing pelanggaran tersebut harus dibuktikan. Oleh karena itu dalam perkara demikian tidak digunakan surat dakwaan subsidiaritas, yang masing-masingnya bersifat substitusi sehingga jika dakwaan primer terbukti maka dakwaan subsider atau lebih subsider lagi tidak perlu dibuktikan lagi.

Hal yang menarik dari temuan ini adalah semua model surat dakwaan yang dikenal dalam doktrin hukum acara pidana, dipergunakan oleh JPU untuk mendakwa pelaku tindak pidana yang merupakan gabungan tindak pidana dari satu perbuatan. Dengan kata lain, tidak terdapat kesamaan atau kesatuan model atau bentuk surat dakwaan dalam menangani perkara pidana tersebut. Kondisi ini menguatkan hasil temuan data primer tahun sebelumnya yang memperlihatkan adanya perbedaan persepsi di antara penegak hukum, baik tentang hukum pidana khusus dan asas lex specialis derogat legi generali, tentang jenis atau nuansa perkara pidana yang harus diterapkan asas tersebut, tahapan dalam proses peradilan pidana, serta model surat dakwaan yang 
digunakan dalam menerapkan asas tersebut. ${ }^{22}$

\section{Model Surat Dakwaan dalam Menerapkan Asas Lex Specialis Derogat Legi Generali dan Tahapan dalam Sistem Peradilan Pidana.}

Dari hasil penelitian, ditemukan bahwa dalam menangani perkara pidana yang memperlihatkan gabungan tindak pidana yang mempertemukan hukum pidana umum dan khusus, atau hukum pidana khusus dengan hukum pidana khusus, penegak hukum menggunakan semua model surat dakwaan yang dikenal dalam doktrin hukum acara pidana. Meski demikian, model terbanyak yang digunakan adalah model subsidiaritas, kumulasi, dan gabungan.

Fakta bahwa masih didakwakannya ketentuan umum dalam surat dakwaan di samping ketentuan khusus, sesungguhnya menunjukkan pandangan penegak hukum bahwa asas tersebut baru diterapkan pada tahap persidangan, tepatnya setelah pembuktian. Kondisi ini berbeda dengan temuan pada tahun sebelumnya, bahwa lebih banyak penegak hukum yang berpandangan bahwa asas ini diterapkan pada tahap penyidikan. Hanya sebagian kecil penegak hukum berpendapat bahwa asas ini diterapkan pada saat penerapan pidana, yaitu setelah dibuktikan di persidangan bahwa perbuatan terdakwa melanggar kedua ketentuan hukum pidana (umum dan khusus), barulah Pasal 63 ayat (2) diterapkan. Dengan kata lain, penerapan pasal tersebut (yang berarti juga penerapan asas lex specialis) hanya berkenaan dengan pidana yang akan diterapkan, yaitu sanksi pidana yang terdapat dalam ketentuan pidana khusus. ${ }^{23}$

Sementara itu, terhadap penggunaan model surat dakwaan kumulasi dalam perkara pidana yang mempertemukan dua atau lebih ketentuan hukum pidana khusus di luar KUHP, mendukung pandangan sebagian penegak hukum, bahwa dalam perkara pidana demikian, asas tersebut tidak diterapkan. Dengan kata lain, dalam kondisi demikian, kedua ketentuan khusus tersebut harus diterapkan secara bersama-sama. Penerapan pidana dalam perkara demikian dapat dijadikan pedoman oleh Pasal 63 ayat (1) atau Pasal 65 KUHP. ${ }^{24}$

\section{Simpulan dan Saran.}

Pasal 63 ayat (2) KUHP menegaskan bahwa terhadap tindak pidana yang melanggar ketentuan umum dan ketentuan khusus sekaligus, hanya dikenakan ketentuan khusus. Ketentuan ini merupakan normatisasi asas lex specialis derogat legi generali dalam hukum pidana. Namun, ketentuan ini tidak memberi pedoman dalam perkara seperti apa terdapat tindak pidana yang melanggar ketentuan umum dan ketentuan khusus sekaligus. Pada praktiknya terjadi ketidaksamaan persepsi di antara penegak hukum, tentang cara menerapkan asas lex sepcialis derogat legi generali, terutama dalam menangani perkara pidana yang merupakan gabungan tindak pidana dari satu perbuatan, yang melanggar ketentuan pidana umum dan ketentuan pidana khusus dalam KUHP (gequalifiseerde delict dan geprivelegieerde delict), melanggar ketentuan pidana umum (KUHP) dan ketentuan pidana khusus di luar KUHP, serta melanggar dua ketentuan hukum pidana khusus (di luar KUHP).

Seharusnya terhadap perkara yang melanggar dua atau lebih ketentuan hukum pidana khusus, tidak dikenakan asas tersebut, karena pada dasarnya dalam perkara demikian, terdapat dua tindak pidana yang berbeda yang diatur dalam dua ketentuan yang berbeda pula. Surat dakwaan dalam perkara demikian juga harus dibuat dengan model kumulasi, sehingga masing-masing pelanggaran ketentuan khusus tersebut harus dibuktikan. Penerapan pidana kemudian dapat menggunakan Pasal 63 ayat (1) atau Pasal 65 KUHP.

\section{DAFTAR PUSTAKA}

Agustina, Shinta, et al, 2010, Persepsi Aparat Penegak Hukum Tentang Implementasi Asas Lex Specialis Derogat Legi Generali Dalam Sistem Peradilan 
Pidana. Laporan Penelitian, LP-UA.

Allen, Ronald Jay, et al, 2002, Comprehensive Criminal Procedure. New York: Aspen Law and Bussiness

Cortens, GJM dan MJ. Borgens, 2011, Het Nederlands Strafprocesrecht, Deventer: Kluwer

De Hullu, J, 2009, Materieel Strafrecht: Over Algemene Leerstukken van Strafrechtelijke aansprakelijkheid naar Nederlands Recht, Vierde druk, Deventer: Kluwer

Enschede, CH. J, 2002, Beginselen Van Strafrecht, Deventer: Kluwer

Harahap, M.Yahya, 2003, Pedoman Pembahasan dan Permasalahan KUHAP. Buku Kedua, Penuntutan dan Persidangan, Jakarta: Kartini Grup

Hiariej, Eddy OS, 2008. Potensi Kejahatan Dalam Analisis Kredit, Materi pelatihan tindak pidana perbankan pada Bank BNI, Yogyakarta.

Hiariej, Eddy OS dkk, 2009. Persepsi dan Penerapan Asas Lex Specialis Derogat Legi Generali di Kalangan Penegak Hukum, Laporan Penelitian, Yogyakarta: Fakultas Hukum Universitas Gajah Mada.

Muladi, 1998, Kapita Selekta Sistem Peradilan Pidana, Semarang: Penerbit Undip.

Lamintang, PAF, 1984, Dasar-dasar Hukum Pidana Indonesia, Bandung: Sinar Baru

Nolte, H.J.A, 1949, Het Strafrecht in De Afzonderlijke Wetten: Rechtshistorisch, Rechtsfilosophisch en Systematische Bewerkt, Utrecht: Dekker \& Van De Vegt NV

Purbacaraka, Purnadi dan Soerjono Soekanto, 1983, Perundang-undangan dan Yurisprudensi, Bandung: Citra Aditya Bakti.

Reksodiputro, Mardjono, 1994, Hak Asasi Manusia dalam Sistem Peradilan Pidana, Jakarta: Lembaga Kriminologi dan Pengkajian Peradilan Indonesia

Smons, 1992, Leerboek van Het Nederlands Strafrecht, Terjemahan Lamintang. Bandung: Pionir Jaya

Smidt, H.J, 1891, Geschiedenis van Het Wetboek van Strafrecht: Volledige Verzameling van Regeeringsontwerpen, Gewisselde Stukken, Gevoerde
Beraadslagingen enz. Eeerste Deel. Haarlem, H.D. Tjeenk Willink

Syarifudin, et.al, 2006, Benang Kusut Peradilan Korupsi Perbankan: Catatan Hasil Eksaminasi Putusan Neloe dkk, Jakarta: Konsorsium Reformasi Hukum Nasional.

Utrecht, 1994, Hukum Pidana II, Surabaya: Pustaka Tinta Mas

Yunto, Emerson, dkk, 2008, Menyelamatkan Pembalak Liar, Hasil Eksaminasi Publik Putusan PN Medan perkara tindak pidana korupsi dan illegal logging, Jakarta: ICW 